\title{
Effect of salinity on chlorophyll and carbohydrate contents of Sesbania grandiflora seedlings
}

\author{
S. Dhanapackiam and M.H. Muhammad llyas \\ Post Graduate and Research Dept. of Botany, Jamal Mohamed College (Autonomous), Trichy, TN. \\ dhanapackiams@yahoo.com
}

\begin{abstract}
The effect of $\mathrm{NaCl}$ salinity concentrations (viz. 10,20,30, 40 and $50 \mathrm{mM} \mathrm{NaCl}$ ) on the contents of chlorophyll a and $b$ and carbohydrate (soluble and insoluble) of Sesbania grandiflora $(\mathrm{L})$ Pers. seedlings were investigated. The investigation showed significant positive influence of higher salinity concentrations on the parameters. The elevated levels of the total soluble and insoluble carbohydrates in the shoot and root are considered to be playing an important role in the osmotic adjustment.
\end{abstract}

Key words: Salinity, chlorophyll, carbohydrate, Sesbania grandiflora.

Introduction

It has been generally recorded that salinity adversely affects seedling growth and some relevant metabolic processes of glycophytic plants (Shaddad \& Zidan, 1989; Hampson \& Simpson, 1990; Zidan \& Al-Zahran 1994). However, the direction and magnitude of these changes varied according to the level and duration of salinization treatment as well as the plant species used. Seeman \& Critchley (1985) and Sharkey et al. (1985) reported that salinity could seriously change the photosynthetic carbon metabolize, leaf chlorophyll content as well as photosynthetic efficiency. Carbohydrates are accumulated in plant tissues under saline stress and these substances are suspected of contributing to osmotic adjustment (Munns \& Termaat, 1986; Delaumey \& Verma, 1993).

Sesbania grandiflora (L) Pers. a plant species, a native of Malaysia is grown in many parts of India, especially Punjab, Delhi, Bengal, Assam and the Andaman's. The effect of salinity on growth and some physiological activities were studied. The present investigation aims at analyzing the effect of $\mathrm{NaCl}$ concentrations on the photosynthetic pigments in 50 day old plants.

\section{Materials and Methods}

Seeds of Sesbania grandiflora were collected from the State Agricultural Forage Department, Coimbatore. The soils for the experimental plants were prepared by mixing red soils, farmyard manure and sand in 3:1:1 ratio. Equal quantity $(\mathrm{W} / \mathrm{W})$ of the soil mixture was taken in earthen pots of uniform size, which comprised $7 \mathrm{~kg} / \mathrm{pot}$. Healthy seeds were sown after soaking in tap water for 12 hours. Five seedlings were retained. The pots with the seedlings were placed under normal sunlight. The plants were irrigated with $10 \mathrm{mM}, 20 \mathrm{mM}, 30 \mathrm{mM}, 40 \mathrm{mM}$ and $50 \mathrm{mM}$ $\mathrm{NaCl}$ of $\mathrm{AR}$ grade along with Knop's nutrient solution.
The first salt treatment $\left(25^{\text {th }}\right.$ day) and the subsequent treatments were given in three stages (after 7 days of each treatment) to avoid any osmotic shock. Control plants were treated with Knop's nutrient solution.

Plants harvested on $50^{\text {th }}$ day after salinization. Five samples were taken for each measurement. The photosynthetic pigments (chlorophyll $a$ and b) were determined according to Arnon (1949). Chlorophyll extract was prepared from fresh leaves $(100 \mathrm{mg})$ by grinding in a tissue homogenizer together with $10 \mathrm{ml}$ of ice cold $80 \%$ acetone. The homogenate was centrifuged at $3000 \mathrm{rpm}$ for 2 minutes. The supernatant was saved and pellet was re-extracted twice with $5 \mathrm{ml}$ of $80 \%$ acetone. All the supernatants were pooled and saved. The absorbance of the extract was read at $663 \mathrm{~nm}, 645$ $\mathrm{nm}$ and $480 \mathrm{~nm}$ using spectronic 1001 plus and the concentration of chlorophyll a, b and total chlorophyll was calculated using Arnon's equations. Soluble and insoluble carbohydrates were determined by the method of Fales (1951). Fresh weight $(100 \mathrm{mg})$ of the leaf tissue from each sample was used using the youngest fully expanded leaf.

\section{Results and Discussion}

The results showed that there was clear effect of salinity concentration on the leaf pigment contents of $S$. grandiflora seedlings (Table 1). It was observed that the high levels of salinization ( 40 and $50 \mathrm{mM} \mathrm{NaCl}$ ) induced a significant decrease in the contents of pigment fractions (chlorophyll $\mathrm{a}$ and $\mathrm{b}$ ) and consequently of the total chlorophyll content as compared with control plants. The total chlorophyll content of the leaves of $S$. grandiflora seedlings exhibited a little increase when grown at 10 and $20 \mathrm{mM} \mathrm{NaCl}$ while the pigment contents increased at the first three treatments $(10,20$ and $30 \mathrm{mM} \mathrm{NaCl})$ and decreased at 40 and $50 \mathrm{mM}$ treatments. Generally, chlorophyll contents were reduced markedly at high saline concentration treatments. This may be due to the
Research article

CIndian Society for Education and Environment (iSee)
"Chlorophyll content \& salinity" http://www.indjst.org
Dhanapackiam \& Muhammed Indian J.Sci.Technol. 
reason that total chlorophyll and proportion of its components depend on the biological process and development stages of the plant and also on the type and concentration of the salt. Ahmed et al. (1978) in Helianthus annus \& Linum usitatissimum and Hajar et al. (1993) in Arachis hypogea obtained similar findings.

\section{Table 1. Pigment contents at different concentration of $\mathrm{NaCl}$} in Sesbania grandiflora Pers. ( $\mathrm{mg} / \mathrm{g}$ fresh wt.)

\begin{tabular}{|c|c|c|c|}
\hline $\mathrm{NaCl}$ & Chlorophyll a & Chlorophyll b & $\begin{array}{c}\text { Total } \\
\text { Chlorophyll }\end{array}$ \\
\hline Control & $6.00 \pm 0.88$ & $3.4 \pm 0.057$ & $9.4 \pm 0.52$ \\
\hline $10 \mathrm{mM}$ & $6.10 \pm 0.057$ & $3.6 \pm 0.033$ & $9.7 \pm 0.185$ \\
\hline $20 \mathrm{mM}$ & $6.10 \pm 0.218$ & $3.7 \pm 0.57$ & $9.7 \pm 0.088$ \\
\hline $30 \mathrm{mM}$ & $4.80 \pm 0.152^{*}$ & $3.1 \pm 0.218^{*}$ & $7.9 \pm 0.218^{*}$ \\
\hline $40 \mathrm{mM}$ & $4.60 \pm 0.088^{*}$ & $3.0 \pm 0.185^{*}$ & $7.6 \pm 0.185^{*}$ \\
\hline $50 \mathrm{mM}$ & $4.6 \pm 0.120^{* *}$ & $2.9 \pm 0.152^{* *}$ & $7.5 \pm 0.186^{* *}$ \\
\hline
\end{tabular}

The data are mean values \pm SE for five plants

*Significant at $1 \%$ level, $\quad$ **Significant at $5 \%$ level

It is clear from Table 1 that chlorophyll a content predominated over chlorophyll $b$. The ratio of chlorophyll $\mathrm{a} / \mathrm{b}$ showed a reduction with increasing saline concentrations, especially $40 \mathrm{mM}$ and $50 \mathrm{mM} \mathrm{NaCl}$. The decreased levels in chlorophyll content under saline stress is commonly reported phenomenon and established that it may be due to different reasons; one of them is related to membrane deterioration (Ashraf \& Bhatti, 2000).

The contents of soluble and insoluble and total carbohydrates in the leaves and roots of the treated seedlings of $S$. grandiflora plants are given in Table 2. It can be seen that the contents of carbohydrates (soluble and insoluble) in the leaves and root tends to increase with increasing salinity level (Table 2). Many plants, which are stressed, by $\mathrm{NaCl}$ salinity, accumulated starch and soluble carbohydrates (Green way \& Munns, 1980; Rathert, 1984). This accumulation has been attributed to impaired carbohydrate utilization (Munns \& Jermaat, 1986). It is apparent from the results that the soluble carbohydrate content in the leaves was higher in salt stress plants compared with control. In contrast, the total carbohydrate in the leaves was much higher than in the root of the treated seedlings (Table 2). This is strong evidence that photosynthesis is the main source of accumulating organic solutes under water stress. Meyer \& Boyer (1981) showed that cutting the photosynthetic cotyledons from Soybean seedlings prevented solute accumulation and osmotic adjustment as also concluded by Kutachera \& Kohler (1994). The accumulation of organic solutes (soluble and insoluble carbohydrates) might play an important role in increasing the internal osmotic pressure (Zidan \& Al- Zahrani, 1994). This has been widely regarded as response to salinity stress condition. While that the photosynthesis is the main source of carbohydrates accumulation, Munns (1993) has been reported that the concentration of sugars and reserve polysaccharides always rise after plants are exposed to salinity in both growing and fully expanded tissues. This is consistent with a blockage in utilization of sugars in the growing tissues and a subsequent build-up in the rest of the plant. A reduction in photosynthesis could be due to feed back inhibition by the high sugar concentrations in the mesophyll cells.

It is appearing in the beginning of growth that $S$. grandiflora seedlings are not deficient in carbohydrates and that the supply of carbon compounds is not limiting their growth. So, after prolonged periods of exposure to salinity the levels of reserve carbohydrates increased, particularly in the leaves.

Table 2. Effect of $\mathrm{NaCl}$ on the root and leaves of total, soluble and insoluble carbohydrate (mg/g/fwt) of Sesbania grandiflora seedlings

\begin{tabular}{|l|l|c|c|c|c|c|c|}
\hline \multirow{2}{*}{ Parameters } & Organs & Control & \multicolumn{5}{|c|}{$\mathrm{NaCl}$ concentrations } \\
\cline { 4 - 7 } \multirow{2}{*}{$\begin{array}{l}\text { Total } \\
\text { carbohydrate }\end{array}$} & Root & $84.4 \pm 0.03$ & $101.3 \pm 0.03$ & $120.8 \pm 0.05$ & $135.0 \pm^{*} 0.02$ & $151.2 \pm 0.06^{*}$ & $164.7 \pm 0.03^{* *}$ \\
\cline { 2 - 7 } & Leaves & $85.0 \pm 0.05$ & $109.1 \pm 0.04$ & $123.8 \pm 0.02$ & $137.2 \pm 0.01^{*}$ & $151.6 \pm 0.04^{*}$ & $165.5 \pm 0.02^{* *}$ \\
\hline $\begin{array}{l}\text { Soluble } \\
\text { carbohydrate }\end{array}$ & Root & $21.0 \pm 0.08$ & $26.6 \pm 0.03$ & $35.2 \pm 0.02$ & $43.8 \pm 0.04^{*}$ & $51.6 \pm 0.01^{* *}$ & $57.9 \pm 0.02^{* *}$ \\
\cline { 2 - 8 } & Leaves & $21.2 \pm 0.03$ & $32.7 \pm 0.06$ & $37.0 \pm 0.05$ & $44.5 \pm 0.02^{*}$ & $51.9 \pm 0.04^{* *}$ & $58.0 \pm 0.01^{* *}$ \\
\hline $\begin{array}{l}\text { Insoluble } \\
\text { carbohydrate }\end{array}$ & Root & $63.4 \pm 0.02$ & $74.7 \pm 0.04$ & $85.6 \pm 0.02$ & $91.2 \pm 0.01^{*}$ & $99.6 \pm 0.04^{* *}$ & $106.8 \pm 0.05^{* *}$ \\
\cline { 2 - 8 } & Leaves & $63.8 \pm 0.05$ & $76.4 \pm 0.03$ & $86.8 \pm 0.01$ & $92.7 \pm 0.07^{*}$ & $99.7 \pm 0.02^{*}$ & $107.5 \pm 0.06^{* *}$ \\
\hline
\end{tabular}

The data are the mean values \pm SE for five plants; * Significant at $1 \%$ level, $\quad$ ** Significant at $5 \%$ level

Research article

CIndian Society for Education and Environment (iSee)
"Chlorophyll content \& salinity" http://www.indjst.org
Dhanapackiam \& Muhammed Indian J.Sci.Technol. 
Reference

1. Ahamed AM, Heikal MM and Shaddad MA (1978) Photosynthetic activity, pigment content and growth of Helianthus annus and Linum usitatissiumm plants as influenced by salinization treatments. Bull. Fac. Sci. Assiut. Univ. 7, 49-56.

2. Arnon, DT (1949) Copper enzymes in isolated Chloroplast polyphenol oxidase in Beta vulgaris. Plant Physiol. 24, 1-15.

3. Al-Zahrani HS, Al-Sobhi OA and Al-Ahmadi SB (2002) Effect of salinity on some physiological activities of Calotropis procera. BioSci. Res. Bull. 18, 107 - 120.

4. Ashraf, MY and Bhatti AS (2000) Effect of salinity on growth and chlorophyll content of Rice. Pak. J. Sci. Ind. Res. 43(2), 130-131.

5. Chaudhary SA and Al-Jowaid AA (1999). Vegetation of the Kingdom of Saudi Arabia. Ministry of Agriculture and Water, Riyadh, KSA.

6. Chavan D and Karadge BA (1986) Growth, mineral nutrition, organic constituents and rate of photosynthesis in Sesbania grandiflora L. Grown under saline conditions. Plant Soil. 93, 395 - 400.

7. Delaumey AJ and Verma DP (1993) Proline biosynthesis and osmoregulation in plants. Plant J. 4, 215-223.

8. Fales FW (1951) The assimilation and degradation of carbohydrates of yeast cells. J. Biol. Chem. 193, 113-116.

9. Greenway H and Munns R (1980) Mechanisms of salts tolerance in non halophytes. Ann. Rev. Plant Physiol. 31, 149-190.

10. Hajar AS, Heikal MM, Maghrabi YM and Abuzinadah RA (1993) Responses of Arachis hypogaea (Peanut) to salinity stress. J. King $A$. Univ. Sci. 5, 5-13.

11. Hampson CR and Simpson GM (1990) Effect of temperature, salt and osmotic potential on early growth of wheat Triticum sativum, I. Germination. Can.J.Bot. 68, 524-528.

12. Kutachera U and Kohler K (1994) Cell elongation, turgor and osmotic pressure in developing sunflower hypocotyls. J. Exp. Bot. 45, 591-595.

13. Meyer RF and Boyer JS (1981) Osmoregulation, solute distribution and growth in soybean seedling having low water potentials. Planta. 151, 482-489.

14. Munns R (1993) Physiological processes limiting plant growth in saline soils: some dogmas and hypotheses. Plant, Cell Environ. 16, 15-24.

15. Munns R and Termaat A (1986) Whole plant responses to salinity. Aust. J. Plant Physiol. 13, 143-160.

16. Rathert G (1984) Sucrose and starch content of plant parts as a possible indicator for salt tolerance of crops. Aust. J. Plant Physiol. 11, 491-495.
Vol.3 No. 1 (Jan 2010)

ISSN: 0974- 6846

17. Seeman JR and Critchley C (1985) Effects of salt stress on the growth, ion content, stomatal behavior and photosynthetic capacity of saltsensitive species Phaseolus vulgaris (L). Planta. 164, 152-162.

18. Shaddad MA and Zidan MA (1989) Effect of $\mathrm{NaCl}$ salinity on the rate germination, sedling growth and some metabolic changes in Raphanus sativus L. and Trigonella Foenum-gracum L. Beitr. Trop. Landwirtsch. Vet. Med., 27, 187-194.

19. Sharkey TD, Seeman JR and Berry JA (1989) Photosynthesis in intact Leaves of C3 Plants: Physics, physiology and rate limitations. Bot. Rev. 51, 53-105.

20. Zidan MA and Al-Zahrani HS (1994) Effect of $\mathrm{NaCl}$ on the germination Seedling and some metabolic changes in Sweet Basil (Ocimum basilicum). Pak. J. Sci. Ind. Res. 37, 541-543.
Dhanapackiam \& Muhammed Indian J.Sci.Technol. 